ARTICLE

Received 4 Feb 2015 | Accepted 5 May 2015 | Published 11 Jun 2015

DOI: $10.1038 /$ ncomms 8402

OPEN

\title{
General synthesis of complex nanotubes by gradient electrospinning and controlled pyrolysis
}

Chaojiang Niu ${ }^{1, \star}$, Jiashen Meng ${ }^{1, \star}$, Xuanpeng Wang ${ }^{1, \star}$, Chunhua Han ${ }^{1}$, Mengyu Yan ${ }^{1}$, Kangning Zhao ${ }^{1}$, Xiaoming $\mathrm{Xu}^{1}$, Wenhao Ren ${ }^{1}$, Yunlong Zhao ${ }^{1,2}$, Lin Xu ${ }^{2}$, Qingjie Zhang ${ }^{1}$, Dongyuan Zhao ${ }^{1}$ \& Liqiang Mai

Nanowires and nanotubes have been the focus of considerable efforts in energy storage and solar energy conversion because of their unique properties. However, owing to the limitations of synthetic methods, most inorganic nanotubes, especially for multi-element oxides and binary-metal oxides, have been rarely fabricated. Here we design a gradient electrospinning and controlled pyrolysis method to synthesize various controllable 1D nanostructures, including mesoporous nanotubes, pea-like nanotubes and continuous nanowires. The key point of this method is the gradient distribution of low-/middle-/high-molecular-weight poly(vinyl alcohol) during the electrospinning process. This simple technique is extended to various inorganic multi-element oxides, binary-metal oxides and single-metal oxides. Among them, $\mathrm{Li}_{3} \mathrm{~V}_{2}\left(\mathrm{PO}_{4}\right)_{3}, \mathrm{Na}_{0.7} \mathrm{Fe}_{0.7} \mathrm{Mn}_{0.3} \mathrm{O}_{2}$ and $\mathrm{Co}_{3} \mathrm{O}_{4}$ mesoporous nanotubes exhibit ultrastable electrochemical performance when used in lithium-ion batteries, sodium-ion batteries and supercapacitors, respectively. We believe that a wide range of new materials available from our composition gradient electrospinning and pyrolysis methodology may lead to further developments in research on 1D systems.

\footnotetext{
${ }^{1}$ State Key Laboratory of Advanced Technology for Materials Synthesis and Processing, Wuhan University of Technology, Wuhan 430070, China. 
O ne-dimensional (1D) nanostructures, including nanowires and nanotubes, have been a focus of nanoscience and nanotechnology, due to the unique low-dimensional properties $^{1-6}$. Various successful fabrication techniques, such as chemical/physical vapour deposition, hydrothermal, template based, electrochemical etching/deposition, laser ablation and electrospinning methods ${ }^{7-15}$, have been developed for specific materials. However, owing to the restriction of applicable objects of each synthetic method and the difference of crystal growth orientation of different substances ${ }^{16-18}, 1 \mathrm{D}$ nanostructures are only achievable for some specific materials. Most inorganic nanotubes, especially for multi-element oxides and binary-metal oxides, have been scarcely obtained, which greatly restricts their further developments. Therefore, a universal technique is required, which can be used to fabricate nanotubes, as well as nanowires, for various inorganic materials with taking no account of the limitation of crystal orientation.

Electrospinning techniques have been studied for the fabrication of conductive polymer nanowires and a part of inorganic material nanowires ${ }^{19-21}$. This method along with different post-treatments has been applied to synthesize some interesting surface multilevel structures (branched nanowires and necklacelike nanowires) and inner multilevel structures (core/shell nanowires and multichannel microtubes) ${ }^{22-26}$. However, most of these structures have been confined to solid nanowires rather than nanotubes. Xia and co-workers have proposed a melt coaxial electrospinning method, with a coaxial spinneret, for fabricating core-shell nanowires and metal nanotubes ${ }^{27-29}$. Jiang and co-workers have developed a multifluidic compound-jet electrospinning technique for fabricating biomimic multichannel microtubes ${ }^{30}$. Nevertheless, it has been rarely proposed to electrospin nanotubes for different kinds of inorganic oxides, especially for multi-element oxides and binary-metal oxides, with abundant materials diversity, low cost, good repeatability and high yield, which seriously limit their further applications.

Here we design a universal gradient electrospinning followed by controlled pyrolysis methodology to synthesize various types of mesoporous nanotubes and pea-like nanotubes (Fig. 1), including multi-element oxides, binary-metal oxides and singlemetal oxides. This strategy is achieved through electrospinning with one ordinary syringe needle while modulating low-, middleand high-molecular-weight poly(vinyl alcohol) (PVA) in the precursor. In this way, different nanotubes are obtained using controllable heat treatments. The resulting mesoporous nanotubes are composed of ultrathin carbon nanotubes $(\sim 5 \mathrm{~nm}$ in thickness and over $10 \mu \mathrm{m}$ in length) and small nanoparticles (approximately 5-20 $\mathrm{nm}$ in diameter) on the tube walls. Pea-like nanotubes are composed of outer carbon nanotubes $(\sim 20 \mathrm{~nm}$ in thickness) and nanoparticles (approximately $100-300 \mathrm{~nm}$ in diameter) in the nanotubes. These structures have larger specific surface area and higher ionic-electronic conductivity compared with traditional nanowires, which exhibits great potential in energy storage fields. Therefore, $\mathrm{Li}_{3} \mathrm{~V}_{2}\left(\mathrm{PO}_{4}\right)_{3}, \mathrm{Na}_{0.7} \mathrm{Fe}_{0.7} \mathrm{Mn}_{0.3} \mathrm{O}_{2}$ and $\mathrm{Co}_{3} \mathrm{O}_{4}$ mesoporous nanotubes were selected as electroactive materials in lithium-ion batteries, sodium-ion batteries and supercapacitors, respectively.

\section{Results}

Gradient electrospinning and controlled pyrolysis mechanism. First, the viscous homogeneous precursor solution was prepared by mixing low-, middle- and high-molecular-weight PVA (in a weight ratio of 3:2:1) and different needed inorganic materials. The precursor solution was then delivered into an ordinary metallic needle at a constant flow rate and electrospun at $20 \mathrm{kV}$. Under the strong electrostatic tension force, the low-, middle- and high-molecular-weight PVA tend to be separated into three layers instead of mixing together. The reasons are as follows: at the same electrospinning conditions, the electric field $(E)$, flow rate $(Q)$, electric current $(I)$, distance $(D)$ between the injector nozzle and the receiver, and other operating characteristics of the low-, middle- and high-molecular-weight PVA are the same. According to the two equations proposed by Baumgarten and Rutledge ${ }^{31,32}$ (equations. 1,2),

$$
\begin{gathered}
R=c \cdot \eta^{1 / 2} \\
R=c(I / Q)^{-2 / 3} \gamma^{1 / 3}
\end{gathered}
$$

where $R$ is the terminal jet radius, $\eta$ is the viscosity, $c$ is a constant, $\gamma$ is the surface tension, $Q$ is the flow rate and $I$ is the electric current. The terminal jet radius $(R)$ is directly proportional to the square root of the viscosity $\left(\eta^{1 / 2}\right)$ and to the cube root of the surface tension $\left(\gamma^{1 / 3}\right)$. The $\eta$ values of the low-, middle- and high-molecular-weight PVA were measured as $0.0766,0.5350$ and $0.7685 \mathrm{dlg}^{-1}$, respectively, increasing gradually. The $\gamma$ values of these three PVA were tested as 40.1, 41.6 and $51.4 \mathrm{mN} \mathrm{m}^{-1}$, respectively (Supplementary Fig. 1a-c, g). Therefore, the high-weight PVA was distributed in the outer layer, the middle-weight PVA was located in the middle layer, and the low-weight PVA was concentrated in the centre in theory (Fig. 1a). To prove this important viewpoint, low-weight PVA was replaced by polyvinyl pyrrolidone (PVP), which has much smaller molecular weight, viscosity and surface tension (Fig. 2a, Supplementary Fig. 1g). After electrospinning low-, middle- and high-molecular-weight PVA composite polymer, the sample is solid nanowires, as shown in transmission electron microscope (TEM) image (Fig. 2b). After replacing the low-weight PVA by PVP, the sample is solid nanowires as well (Fig. 2c). Herein, PVP can be dissolved in trichloromethane $\left(\mathrm{CHCl}_{3}\right)$ solution, but PVA can not be dissolved in it. Therefore, the composite polymer nanowires were soaked in the $\mathrm{CHCl}_{3}$ to remove PVP, getting middle-/high-molecular-weight PVA polymer nanotubes (Fig. 2d), which can clearly prove the layered distribution of low-, middle- and high-molecular-weight PVA. At the same time, the inorganic materials were homogeneously dispersed in all three layers.

After the electrospinning process, the composite nanowires were presintered in air. According to the thermogravimetric curves, the differentials of the mass loss $(M)$ and temperature $(T)$ $(\mathrm{d} M / \mathrm{d} T)$ of the low-, middle- and high-weight PVA are -1.50 , -0.95 and -0.58 , respectively (Supplementary Fig. 1d,e). Consequently, the inner low-weight PVA first pyrolyzes and shrinks as the temperature is slowly increased, and moves towards the boundary of the low-/middle-weight PVA, carrying the inorganic materials simultaneously, thereby leading to the formation of nanotubes ${ }^{33}$. By this analogy, the middle-weight PVA then pyrolyzes and moves towards the middle-/high-weight PVA, together with the inorganic materials, thereby leading to the expansion of the inner diameter of nanotubes, as illustrated in Fig. 1a. Finally, all of the preliminarily decomposed PVA and inorganic materials converge together on the outer tubes. At last, inorganic mesoporous nanotubes can be obtained after sintering in air, which are only composed of tiny inorganic nanoparticles. Mesopores are formed via the decomposition of the inorganic materials and the partial pyrolysis of PVA. On the other hand, after high-temperature sintering under argon, all of the PVA carbonize, resulting in composite mesoporous nanotubes, which are composed of uniform inorganic nanoparticles and ultrathin carbon nanotubes.

For pea-like nanotubes, the preliminary electrospinning process of pea-like nanotubes is the same as that of the mesoporous nanotubes. After electrospinning, the composite 


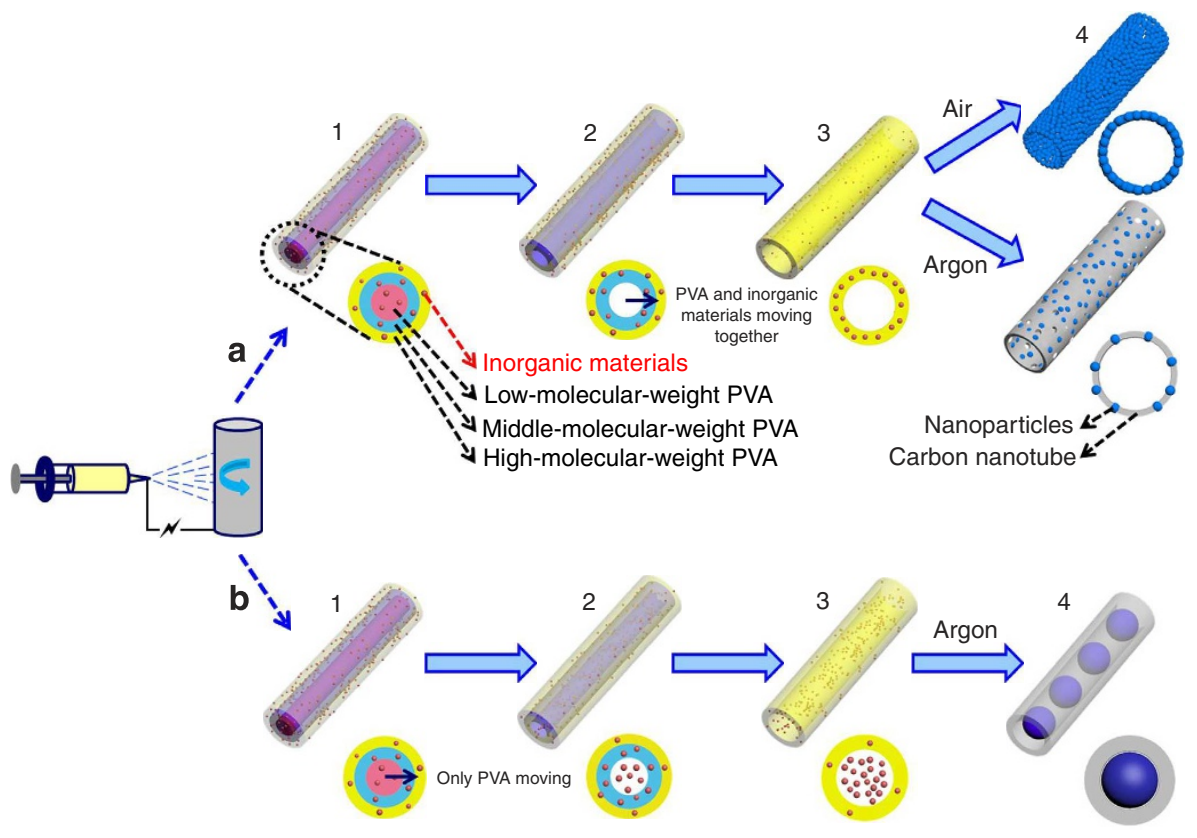

Figure 1 | Schematics of the gradient electrospinning and controlled pyrolysis method. (a) Preparation process of mesoporous nanotubes. (1) After the electrospinning process, the low-, middle- and high-molecular-weight PVA tend to be distributed into three layers in the radial direction of composite nanowires. (2) As the temperature is slowly increased, the inner low-weight PVA first pyrolyses and moves towards the boundary of the low-/middleweight PVA, carrying the inorganic materials. Then the middle-weight PVA pyrolyses and moves towards the high-weight PVA as well. (3) All of the preliminary pyrolysed PVA and inorganic materials converge together in the tube walls. (4) After sintering in air, all of the PVA pyrolyse and uniform mesoporous nanotubes are obtained, which are composed of tiny inorganic nanoparticles. On the other hand, after high-temperature sintering under argon, PVA carbonize, uniform mesoporous nanotubes are also obtained, which consists of inorganic nanoparticles and carbon nanotubes. The mesopores result from the decomposition of the inorganic materials and a part of PVA polymers. (b) Preparation process of pea-like nanotubes. (1) After the electrospinning process, the composite nanowires are directly and immediately placed into a furnace in air, which is preheated to and maintained at $300^{\circ} \mathrm{C}$. $(2,3)$ All of the PVA decompose at the same time and rapidly move towards the outer high-weight PVA layer without carrying the inorganic materials, leaving them in the centre. (4) After high-temperature sintering under argon, the outer PVA carbonize and the inner inorganic materials develop into nanoparticles, forming pea-like nanotubes.

a
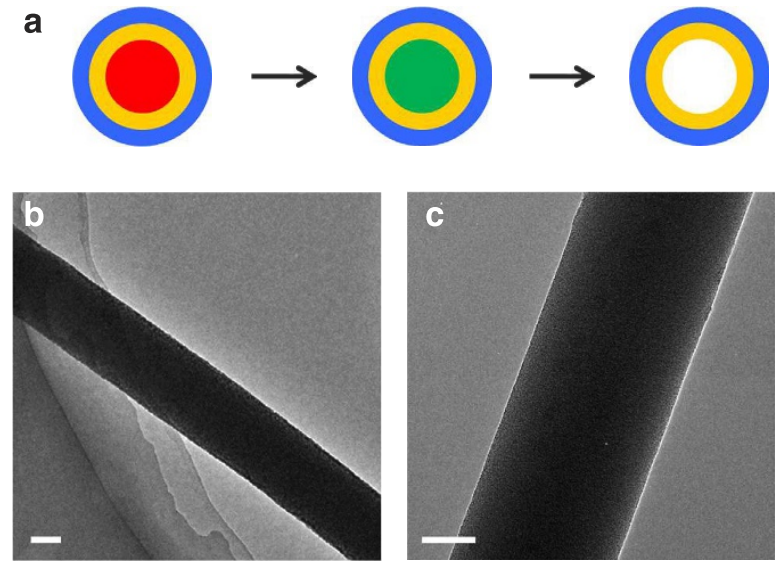

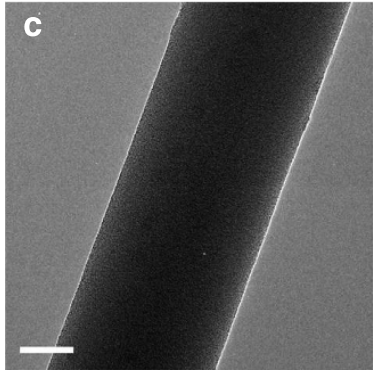

High-molecular-weight PVA

Middle-molecular-weight PVA

Low-molecular-weight PVA

Polyvinyl pyrrolidone (PVP)

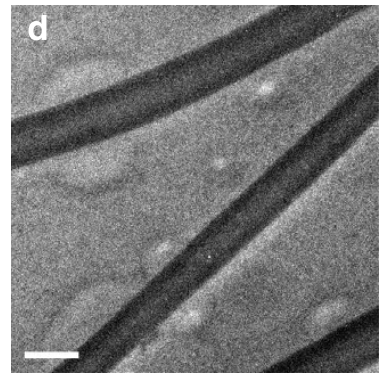

Figure 2 | Schematic and characterization of the gradient distribution of low-/middle-/high-molecular-weight PVA. (a) Schematic of the process of replacing low-molecular-weight PVA by PVP, then removing PVP with trichloromethane, to prove the layered distribution of low-, middle- and high-molecular-weight PVA. (b) TEM image of low-, middle- and high-molecular-weight PVA composite polymer nanowire after electrospinning with a scale bar at $100 \mathrm{~nm}$. (c) TEM image of PVP and middle-/high-molecular-weight PVA composite polymer nanowire after electrospinning with a scale bar at $50 \mathrm{~nm}$. Low-molecular-weight PVA is replaced by PVP. (d) TEM image of middle-/high-molecular-weight PVA polymer nanotubes with a scale bar at $500 \mathrm{~nm}$, after removing PVP in the inner center using $\mathrm{CHCl}_{3}$.

nanowires were directly and immediately placed into the furnace, which was preheated to $300^{\circ} \mathrm{C}$ in air. At this temperature, all of the low-/middle-/high-weight PVA simultaneously decompose (Supplementary Fig. 1d) and quickly move towards the outer high-weight PVA layer without carrying the inorganic materials in the radial direction (Fig. 1b). Thus, the inorganic materials are left in situ in the centre of the nanotubes. When the samples are annealed at high temperature under argon, the outer preliminary decomposed PVA carbonize and form carbon nanotubes, whereas the inner inorganic materials develop into nanoparticles, which are uniformly dispersed in the nanotubes. Eventually, pea-like nanotubes are obtained. 
To confirm the mechanism of our gradient electrospinning and controlled pyrolysis method, various inorganic materials were electrospun into mesoporous nanotubes and pea-like nanotubes according to the aforementioned procedures (Fig. 3). First, multielement oxides $\left(\mathrm{Li}_{3} \mathrm{~V}_{2}\left(\mathrm{PO}_{4}\right)_{3}, \mathrm{Na}_{3} \mathrm{~V}_{2}\left(\mathrm{PO}_{4}\right)_{3}, \mathrm{Na}_{0.7} \mathrm{Fe}_{0.7} \mathrm{Mn}_{0.3} \mathrm{O}_{2}\right.$ and $\mathrm{LiNi}_{1 / 3} \mathrm{Co}_{1 / 3} \mathrm{Mn}_{1 / 3} \mathrm{O}_{2}$ ) were electrospun into uniform mesoporous nanotubes with a diameter of $\sim 200 \mathrm{~nm}$. Then, the binary-metal oxides $\left(\mathrm{LiMn}_{2} \mathrm{O}_{4}, \mathrm{LiCoO}_{2}, \mathrm{NiCo}_{2} \mathrm{O}_{4}\right.$ and $\left.\mathrm{LiV}_{3} \mathrm{O}_{8}\right)$ were electrospun into mesoporous nanotubes with a diameter of $\sim 150 \mathrm{~nm}$. For single-metal oxides $\left(\mathrm{CuO}, \mathrm{Co}_{3} \mathrm{O}_{4}, \mathrm{SnO}_{2}\right.$ and $\mathrm{MnO}_{2}$ ), mesoporous nanotubes with a smaller diameter of $\sim 50 \mathrm{~nm}$ were fabricated. For the pea-like nanotubes, $\mathrm{Co}, \mathrm{LiCoO}_{2}$, $\mathrm{Li}_{3} \mathrm{~V}_{2}\left(\mathrm{PO}_{4}\right)_{3}$ and $\mathrm{Na}_{0.7} \mathrm{Fe}_{0.7} \mathrm{Mn}_{0.3} \mathrm{O}_{2}$ were selected from the different species, the outer layer was carbon and the inner particles were different inorganic salts. Additional scanning electron microscope (SEM) images and corresponding X-ray diffraction patterns of each sample are presented as well (Supplementary Figs 2 and 3). The detailed processes are clearly illustrated in the Methods section. Each precursor solution was electrospun at a constant flow rate of $\sim 0.1 \mathrm{ml} \mathrm{h}^{-1}$ using one ordinary syringe needle $(10 \mathrm{ml})$, and the corresponding production of inorganic materials was as high as $\sim 0.6 \mathrm{mmol} \mathrm{h}^{-1}$ and $\sim 900 \mathrm{~cm}^{2}$ of aluminium foil for each run (Supplementary
Fig. 1f), which was a large yield. And these products can also be collected in a parallel array around the rotating wheel, to improve the packing density. ${ }^{34}$

Electrochemical characterization. In energy-storage fields, most electrodes reported previously for batteries and supercapacitors suffer problems associated with a low conductivity, a small electrolyte/electrode surface area and self-aggregation during the charge/discharge process, leading to unsatisfactory performance, which greatly limits their applications ${ }^{35-45}$. One-dimensional nanomaterials have widely been investigated and applied in energy storage fields due to its unique low-dimensional properties. Remarkably, our complex nanotubes, especially mesoporous nanotubes, have the characteristics of large surface area, excellent stability and continuous carbon nanotubes with high conductivity and so on, which is expected to effectively improve the electrochemical performance of electrodes (Fig. 4). Therefore, to confirm it, $\mathrm{Li}_{3} \mathrm{~V}_{2}\left(\mathrm{PO}_{4}\right)_{3}, \mathrm{Na}_{0.7} \mathrm{Fe}_{0.7} \mathrm{Mn}_{0.3} \mathrm{O}_{2}$ and $\mathrm{Co}_{3} \mathrm{O}_{4}$ mesoporous nanotubes were selected and measured as typical examples of electroactive materials in lithium-ion batteries, sodium-ion batteries and supercapacitors, respectively.

First, the $\mathrm{Li}_{3} \mathrm{~V}_{2}\left(\mathrm{PO}_{4}\right)_{3}$ mesoporous nanotubes were further characterized, measured and compared with the $\mathrm{Li}_{3} \mathrm{~V}_{2}\left(\mathrm{PO}_{4}\right)_{3}$

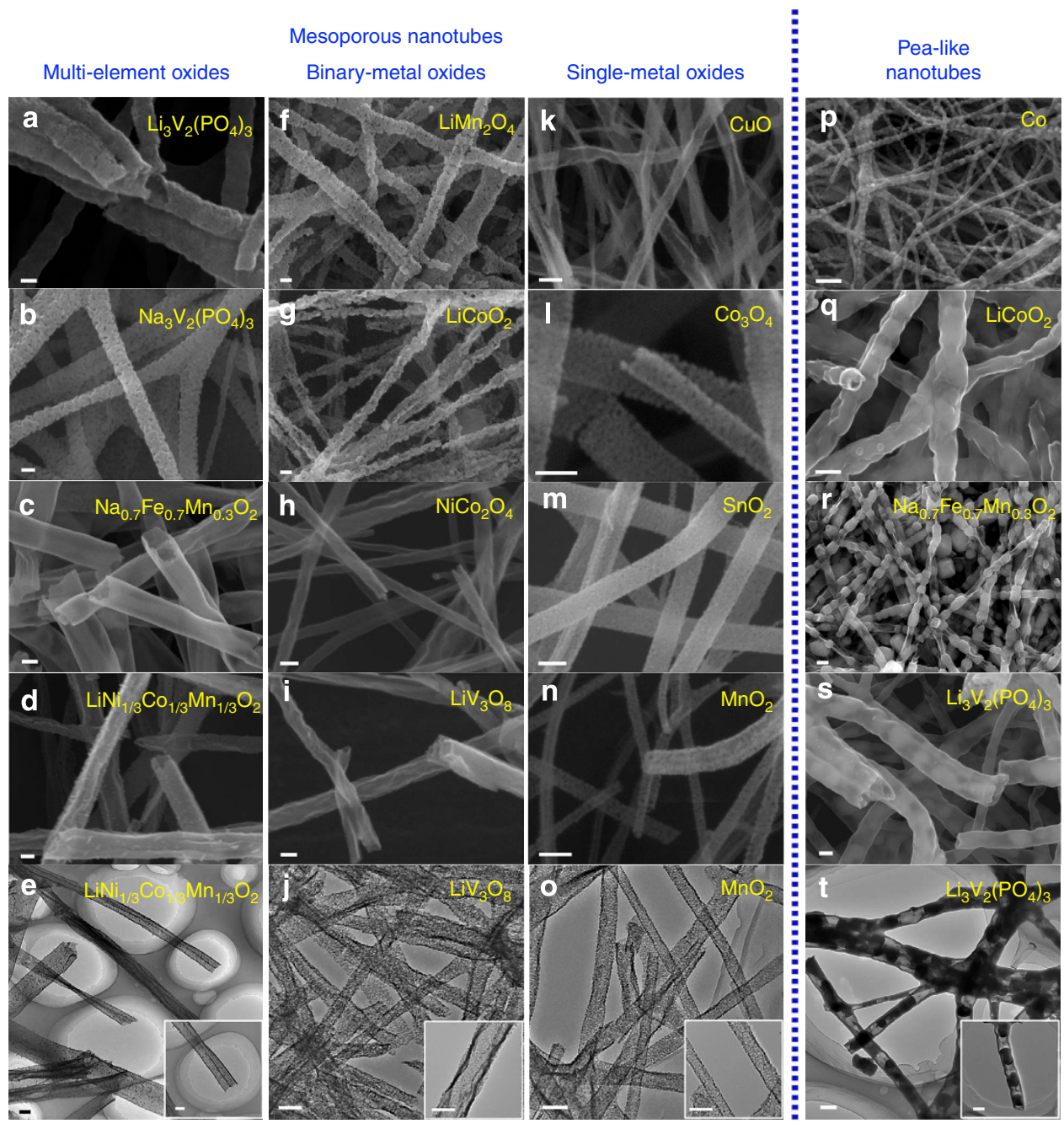

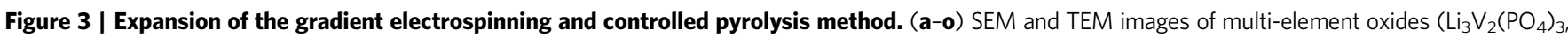
$\mathrm{Na}_{3} \mathrm{~V}_{2}\left(\mathrm{PO}_{4}\right)_{3}, \mathrm{Na}_{0.7} \mathrm{Fe}_{0.7} \mathrm{Mn}_{0.3} \mathrm{O}_{2}$ and $\left.\mathrm{LiNi}_{1 / 3} \mathrm{Co}_{1 / 3} \mathrm{Mn}_{1 / 3} \mathrm{O}_{2}\right)$, binary-metal oxides $\left(\mathrm{LiMn}_{2} \mathrm{O}_{4}, \mathrm{LiCoO}_{2}, \mathrm{NiCo}_{2} \mathrm{O}_{4}\right.$ and LiV $\left.\mathrm{O}_{8}\right)$ and single-metal oxides $(\mathrm{CuO}$, $\mathrm{Co}_{3} \mathrm{O}_{4}, \mathrm{SnO}_{2}$ and $\mathrm{MnO}_{2}$ ) mesoporous nanotubes, respectively, scale bars, $100 \mathrm{~nm}$. (p-t) SEM and TEM images of pea-like nanotubes $\left(\mathrm{Co}_{1}, \mathrm{LiCoO}_{2}, \mathrm{Li} \mathrm{V}_{2}\left(\mathrm{PO}_{4}\right)_{3}\right.$ and $\mathrm{Na}_{0.7} \mathrm{Fe}_{0.7} \mathrm{Mn}_{0.3} \mathrm{O}_{2}$ ) from different species with scale bars at $200 \mathrm{~nm}$. The scale bars for the inset TEM images $(\mathbf{e}, \mathbf{j}, \mathbf{0}, \mathbf{t})$ are $100 \mathrm{~nm}$. 
a
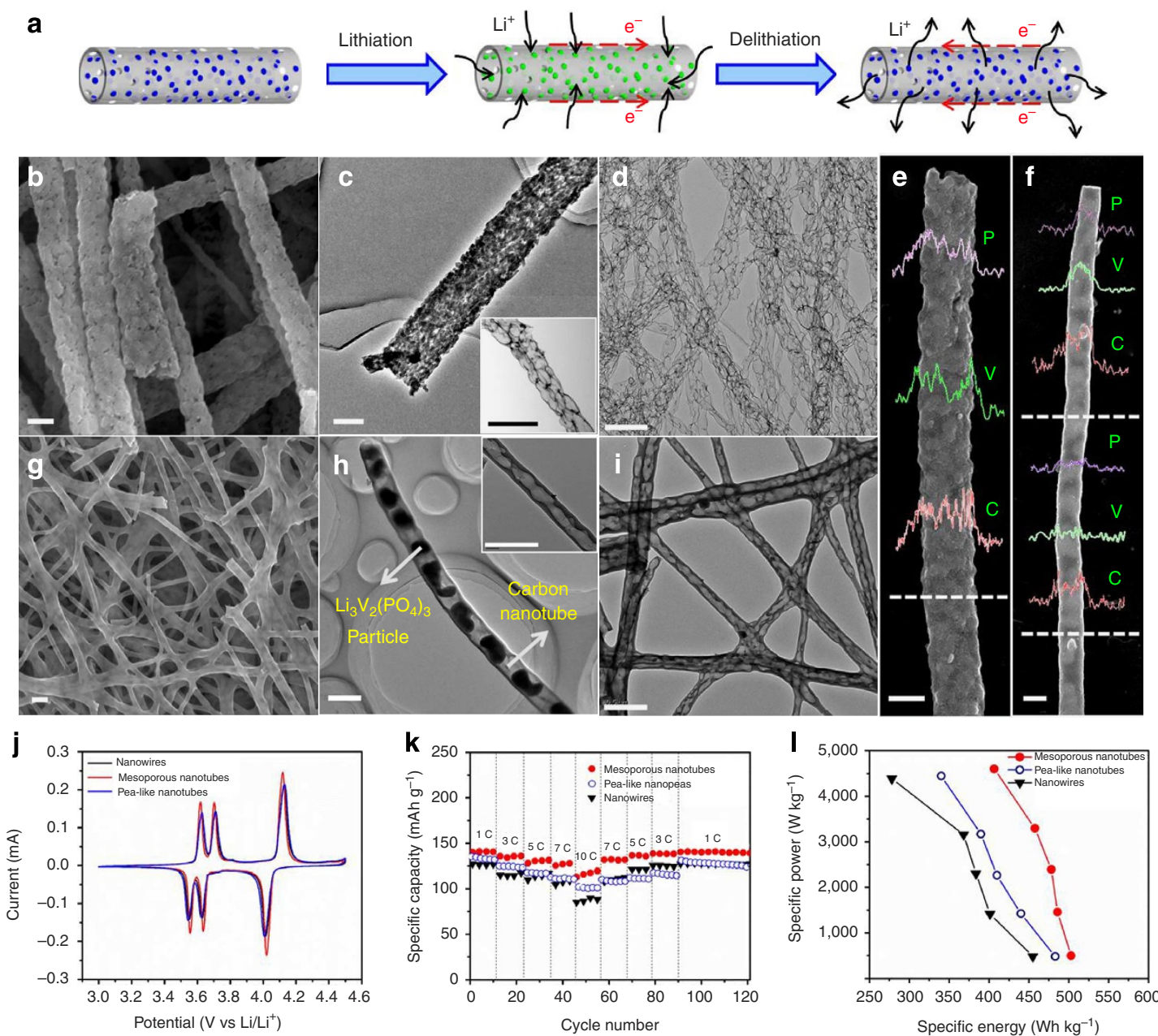

m

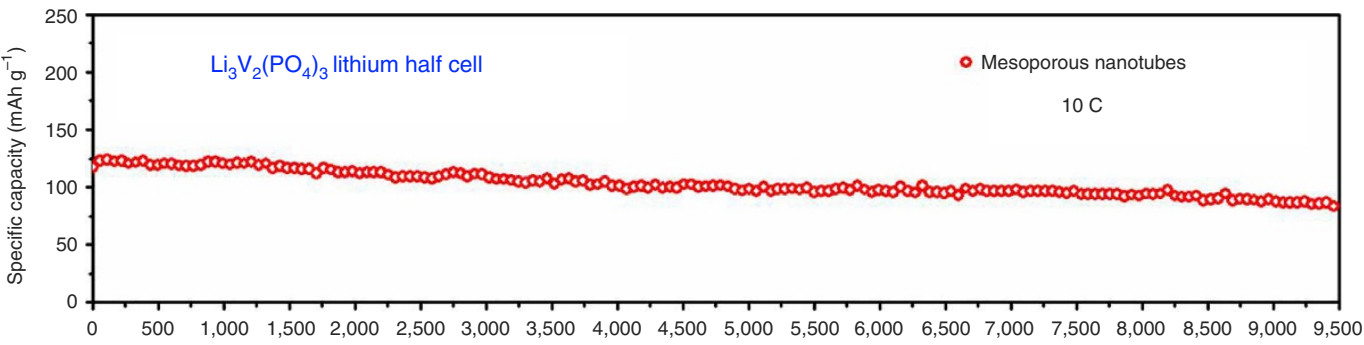

n

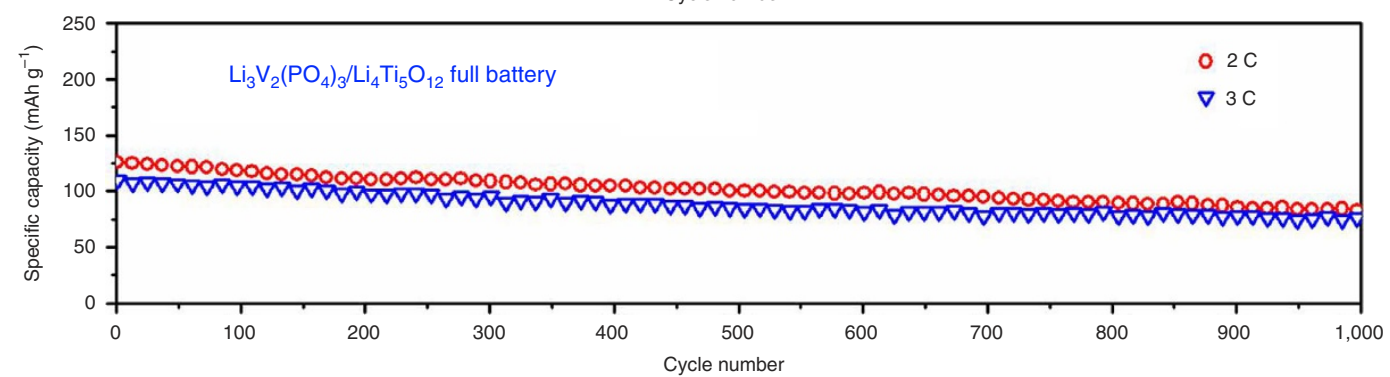

Figure 4 | Characterization and electrochemical performance in lithium-ion batteries. (a) Schematic of the lithiation and delithiation processes of mesoporous nanotubes. (b,c), SEM and TEM images of $\mathrm{Li}_{3} \mathrm{~V}_{2}\left(\mathrm{PO}_{4}\right)_{3}$ mesoporous nanotubes with scale bar at $200 \mathrm{~nm}$. (d) and the inset of (c), TEM images of ultrathin carbon nanotubes after the $\mathrm{Li}_{3} \mathrm{~V}_{2}\left(\mathrm{PO}_{4}\right)_{3}$ was removed using hydrogen fluoride with scale bar at $500 \mathrm{~nm}$. (e,f) Energy-dispersive $\mathrm{X}$-ray spectra (EDS) line scans of $\mathrm{Li}_{3} \mathrm{~V}_{2}\left(\mathrm{PO}_{4}\right)_{3}$ mesoporous nanotubes (e) and pea-like nanotubes (f) with scale bar at $200 \mathrm{~nm}$, respectively. (g,h) SEM and TEM images of $\mathrm{Li}_{3} \mathrm{~V}_{2}\left(\mathrm{PO}_{4}\right)_{3}$ pea-like nanotubes with scale bar at $500 \mathrm{~nm}$. (i) and the inset of $(\mathbf{h}) \mathrm{TEM}$ images of carbon nanotubes after removing $\mathrm{Li}_{3} \mathrm{~V}_{2}\left(\mathrm{PO}_{4}\right)_{3}$ with hydrogen fluoride with scale bar at $500 \mathrm{~nm}$. (j) Cyclic voltammograms (CV) of the half cells collected at a sweep rate of $0.1 \mathrm{mV} \mathrm{s}^{-1}$ in the potential ranging from 3 to $4.5 \mathrm{~V}$ versus $\mathrm{Li} / \mathrm{Li}^{+}$. ( $\left.\mathbf{k}, \mathbf{I}\right)$ Rate performance and the corresponding Ragone plots of these three cathodes measured at the rates of $1,3,5,7$ and 10 C, respectively. $(\mathbf{m})$ Long cycling performance of $\mathrm{Li}_{3} \mathrm{~V}_{2}\left(\mathrm{PO}_{4}\right)_{3}$ mesoporous nanotubes measured at $10 \mathrm{C}$ for a large number of $9,500 \mathrm{cycles}$ in a lithium half cell. (n) Cycling performance of $\mathrm{Li}_{3} \mathrm{~V}_{2}\left(\mathrm{PO}_{4}\right)_{3} / \mathrm{Li}_{4} \mathrm{Ti}_{5} \mathrm{O}_{12}$ lithium-ion full batteries measured at 2 and $3 \mathrm{C}$ for 1,000 cycles $\left(1 \mathrm{C}\right.$ equals to $\left.133 \mathrm{mAg}{ }^{-1}\right)$. 
pea-like nanotubes and solid nanowires (Supplementary Figs. 4-7). The $\mathrm{Li}_{3} \mathrm{~V}_{2}\left(\mathrm{PO}_{4}\right)_{3}$ mesoporous nanotubes consist of ultrathin, continuous, mesoporous carbon nanotubes $(\sim 200 \mathrm{~nm}$ in diameter) and $\mathrm{Li}_{3} \mathrm{~V}_{2}\left(\mathrm{PO}_{4}\right)_{3}$ nanoparticles (approximately $20-50 \mathrm{~nm}$, uniformly dispersed on the tubes) (Fig. $4 \mathrm{~b}-\mathrm{d}$ ), which is clearly confirmed by removal of the $\mathrm{Li}_{3} \mathrm{~V}_{2}\left(\mathrm{PO}_{4}\right)_{3}$ with hydrogen fluoride.
Moreover, the mesopore size can also be tuned by modulating the sintering temperature (Supplementary Fig. 5). In contrast, the $\mathrm{Li}_{3} \mathrm{~V}_{2}\left(\mathrm{PO}_{4}\right)_{3}$ pea-like nanotubes are composed of outer thick carbon nanotubes $(\sim 200 \mathrm{~nm}$ in diameter and $\sim 20 \mathrm{~nm}$ in wall thickness) and $\mathrm{Li}_{3} \mathrm{~V}_{2}\left(\mathrm{PO}_{4}\right)_{3}$ nanoparticles in the nanotubes ( $\sim 200 \mathrm{~nm}$ in diameter), which uniformly separate from each a

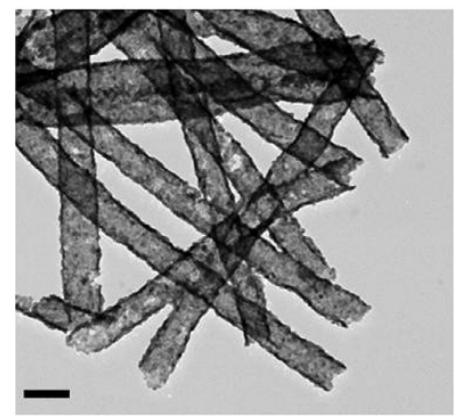

b

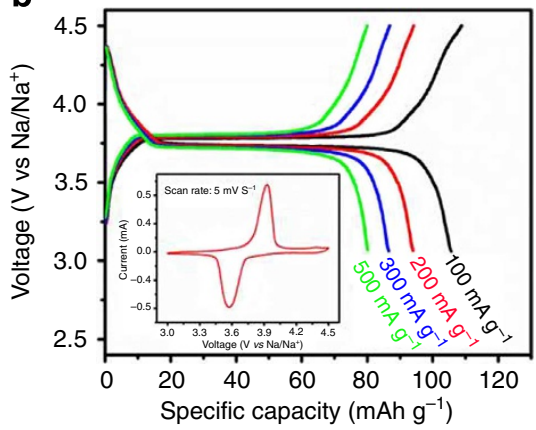

Specific capacity $\left(\mathrm{mAh} \mathrm{g}^{-1}\right)$

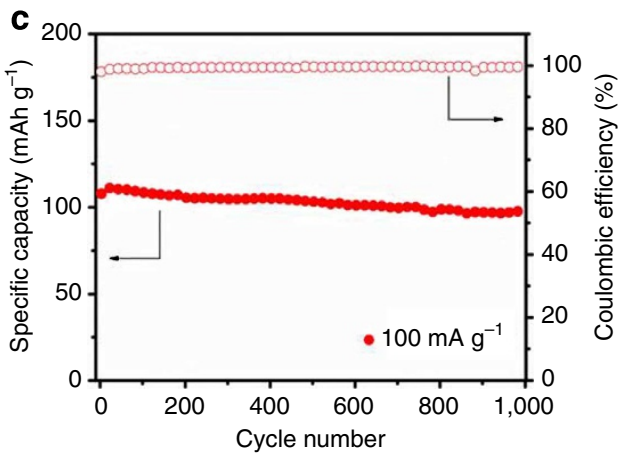

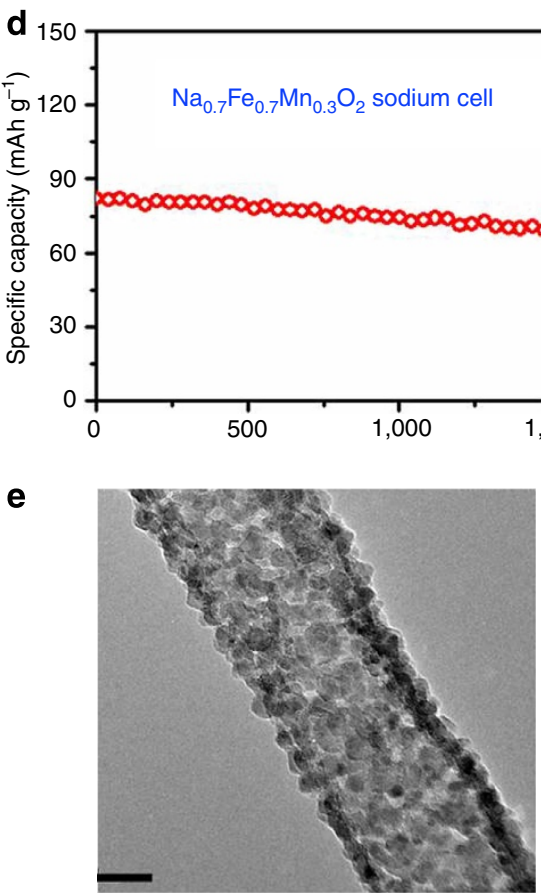

- $500 \mathrm{~mA} \mathrm{~g}^{-1}$

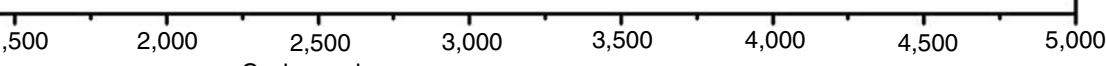

Cycle number
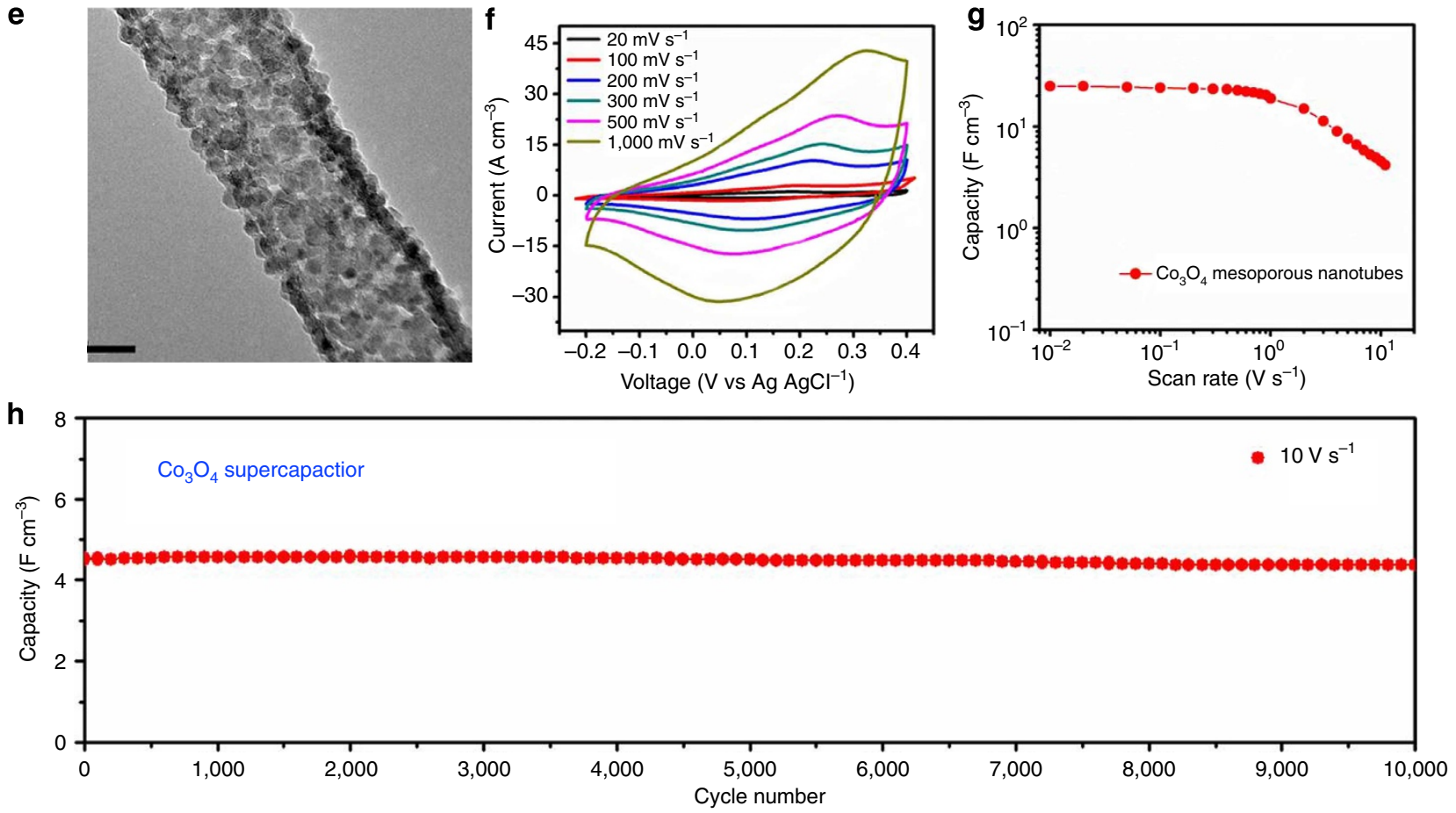

Figure 5 | Characterization and electrochemical performance in sodium-ion batteries and supercapacitors. (a) $\mathrm{TEM}^{\mathrm{image}}$ of the $\mathrm{Na}_{0.7} \mathrm{Fe}_{0.7} \mathrm{Mn}_{0.3} \mathrm{O}_{2}$ mesoporous nanotubes with a scale at $200 \mathrm{~nm}$. (b) Charge-discharge curves of $\mathrm{Na}_{0.7} \mathrm{Fe}_{0.7} \mathrm{Mn}_{0.3} \mathrm{O}_{2}$ measured at 100, 200, 300 and $500 \mathrm{mAg}$,

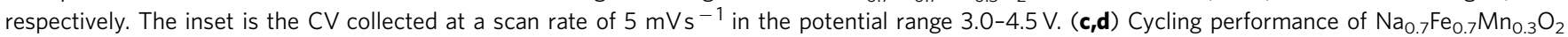
mesoporous nanotubes tested for 1,000 cycles at $100 \mathrm{mAg}^{-1}$ and for 5,000 cycles at $500 \mathrm{mAg}^{-1}$ (e) TEM image of $\mathrm{Co}_{3} \mathrm{O}_{4}$ mesoporous nanotubes with scale bar at $20 \mathrm{~nm}$. (f) CV curves obtained at different scan rates from 20,100,300, 500 to $1,000 \mathrm{mVs}^{-1}$, respectively. (g) Stack capacitance of $\mathrm{Co}_{3} \mathrm{O}_{4}$ mesoporous nanotubes versus scan rate. (h) Long cycling performance of $\mathrm{Co}_{3} \mathrm{O}_{4}$ mesoporous nanotubes tested for 10,000 times at a high rate of $10 \mathrm{Vs}-1$. 
other (Fig. 4g-i). The EDS line scans demonstrate the homogeneous distribution of $\mathrm{V}, \mathrm{P}$ and $\mathrm{C}$ in mesoporous nanotubes, and display the difference between the hollow and solid parts in pea-like nanotubes (Fig. 4e,f). The carbon mass content of $\mathrm{Li}_{3} \mathrm{~V}_{2}\left(\mathrm{PO}_{4}\right)_{3}$ mesoporous nanotubes is only $7 \%$, which is much smaller compared with pea-like nanotubes (17\%) and nanowires (12\%; Supplementary Fig. 4). $\mathrm{Li}_{3} \mathrm{~V}_{2}\left(\mathrm{PO}_{4}\right)_{3}$ mesoporous nanotubes exhibit higher capacity and better rate recovery $(100 \%)$ than pea-like nanotubes (94\%) and nanowires (98\%) when tested at various rates ranging from $1,3,5,7$ to $10 \mathrm{C}$, demonstrating prominent rate performance (Fig. $4 \mathrm{j}-\mathrm{l}$ ). Particularly, $\mathrm{Li}_{3} \mathrm{~V}_{2}\left(\mathrm{PO}_{4}\right)_{3}$ mesoporous nanotubes can operate stably for as long as 9,500 cycles at the high rate of $10 \mathrm{C}$. The 9,500th discharge capacity is $86 \mathrm{mAhg}^{-1}$, which corresponds to a capacity retention of $80 \%$ and to a capacity fading of $0.0024 \%$ per cycle (Fig. $4 \mathrm{~m}$ ). However, the capacity retentions of $\mathrm{Li}_{3} \mathrm{~V}_{2}\left(\mathrm{PO}_{4}\right)_{3}$ pea-like nanotubes and solid nanowires are only $71 \%$ and $68 \%$, respectively, after being cycled only 1,100 times at $10 \mathrm{C}$ (Supplementary Fig. 6a). Then further electrochemical measurements of $\mathrm{Li}_{3} \mathrm{~V}_{2}\left(\mathrm{PO}_{4}\right)_{3}$ mesoporous nanotubes were implemented. When $\mathrm{Li}_{3} \mathrm{~V}_{2}\left(\mathrm{PO}_{4}\right)_{3}$ mesoporous nanotubes were measured at different temperatures of $-20,20$ and $60^{\circ} \mathrm{C}$ at a rate of $5 \mathrm{C}$, the corresponding initial capacities were 103,131 and $136 \mathrm{mAhg}^{-1}$, respectively (Supplementary Fig. 6c,d). And the coulombic efficiency of $\mathrm{Li}_{3} \mathrm{~V}_{2}\left(\mathrm{PO}_{4}\right)_{3}$ mesoporous nanotubes can be kept on $\sim 100 \%$ when tested at $1 \mathrm{C}\left(133 \mathrm{mAhg}^{-1}\right)$ for 500 cycles (Supplementary Fig. 6e). In the meantime, we assembled $\mathrm{Li}_{3} \mathrm{~V}_{2}\left(\mathrm{PO}_{4}\right)_{3} / \mathrm{Li}_{4} \mathrm{Ti}_{5} \mathrm{O}_{12}$ lithium-ion full batteries. $\mathrm{Li}_{4} \mathrm{Ti}_{5} \mathrm{O}_{12}$ was selected as the anode because of its stable charge/discharge plateau (Supplementary Fig. $7 \mathrm{a}-\mathrm{c}$ ). This full battery delivers capacities of 118, 93, 80 and $74 \mathrm{mAhg}^{-1}$ at the rates of 2, 3, 4 and $5 \mathrm{C}$, respectively, and recovers $96 \%$ of its initial capacity when the rate is decreased back to $2 \mathrm{C}$ (Supplementary Fig. 7d). Notably, the $\mathrm{Li}_{3} \mathrm{~V}_{2}\left(\mathrm{PO}_{4}\right)_{3} /$ $\mathrm{Li}_{4} \mathrm{Ti}_{5} \mathrm{O}_{12}$ battery is stably charged/discharged for over 1,000 cycles at rates of 2 and $3 \mathrm{C}$, with a capacity retention of $73 \%$ and $75 \%$, respectively (Fig. $4 \mathrm{n}$ ), demonstrating an excellent cycling performance and great commercial potential.

The superior performance is explained as follows: (1) $\mathrm{Li}_{3} \mathrm{~V}_{2}\left(\mathrm{PO}_{4}\right)_{3}$ mesoporous nanotubes contain ultrathin continuous carbon nanotubes. The charge transfer resistance (Rct) of $\mathrm{Li}_{3} \mathrm{~V}_{2}\left(\mathrm{PO}_{4}\right)_{3}$ mesoporous nanotubes is measured as $56 \Omega$, much smaller than that of nanowires $(115 \Omega)$, which can obviously improve the electronic conductivity ${ }^{36}$ (Supplementary Fig. 6b). (2) $\mathrm{Li}_{3} \mathrm{~V}_{2}\left(\mathrm{PO}_{4}\right)_{3}$ mesoporous nanotubes exhibit the largest specific surface area $\left(115 \mathrm{~m}^{2} \mathrm{~g}^{-1}\right)$ among mesoporous nanotubes, pea-like nanotubes $\left(33 \mathrm{~m}^{2} \mathrm{~g}^{-1}\right)$ and nanowires $\left(15 \mathrm{~m}^{2} \mathrm{~g}^{-1}\right)$, which is beneficial to increase the electrode-electrolyte contact area and the active sites $^{39,40}$ (Supplementary Fig. 4). (3) These nanotubes have abundant mesopores on the tube walls, which can effectively buffer the stress induced during the charge/discharge process, and greatly improve the structural stability ${ }^{40}$ (Fig. 4a).

The $\mathrm{Na}_{0.7} \mathrm{Fe}_{0.7} \mathrm{Mn}_{0.3} \mathrm{O}_{2}$ mesoporous nanotubes are also composed of ultrathin carbon nanotubes $(\sim 200 \mathrm{~nm}$ in diameter $)$ and $\mathrm{Na}_{0.7} \mathrm{Fe}_{0.7} \mathrm{Mn}_{0.3} \mathrm{O}_{2}$ nanoparticles $(\sim 10 \mathrm{~nm})$ on the tubes (Fig. $5 \mathrm{a}$ ). And the X-ray diffraction pattern, ICP measurement and highresolution TEM demonstrate the rhombohedral crystal structure of $\mathrm{Na}_{0.7} \mathrm{Fe}_{0.7} \mathrm{Mn}_{0.3} \mathrm{O}_{2}$ (Supplementary Fig. 8). Stable voltage plateaus are observed when measured at the current densities of $100,200,300$ and $500 \mathrm{mAg}^{-1}$, respectively, corresponding to one pair of well-defined anodic $(3.9 \mathrm{~V})$ and cathodic $(3.6 \mathrm{~V})$ peaks (Fig. 5b). When $\mathrm{Na}_{0.7} \mathrm{Fe}_{0.7} \mathrm{Mn}_{0.3} \mathrm{O}_{2}$ mesoporous nanotubes are tested at a low density of $100 \mathrm{mAg}^{-1}$ in the potential range $3-4.5 \mathrm{~V}, 90 \%$ of the initial capacity $\left(109 \mathrm{mAh} \mathrm{g}^{-1}\right)$ is retained after 1,000 cycles (Fig. 5c). When measured at a high current density of $500 \mathrm{~mA} \mathrm{~g}^{-1}, 70 \%$ of the initial capacity $\left(82 \mathrm{mAh} \mathrm{g}^{-1}\right)$ is maintained after cycling as long as 5,000 times, corresponding to a capacity fading of $0.0071 \%$ per cycle (Fig. 5d). Compared with the conventional $\mathrm{Na}_{0.7} \mathrm{Fe}_{0.7} \mathrm{Mn}_{0.3} \mathrm{O}_{2}$ nanoparticles, which were synthesized as a control sample, our $\mathrm{Na}_{0.7} \mathrm{Fe}_{0.7} \mathrm{Mn}_{0.3} \mathrm{O}_{2}$ mesoporous nanotubes exhibit much higher specific capacity and better cycling performance (Supplementary Figs 8 and 9). Another comparison with those previously reported results for sodium-ion batteries reveals that our $\mathrm{Na}_{0.7} \mathrm{Fe}_{0.7} \mathrm{Mn}_{0.3} \mathrm{O}_{2}$ mesoporous nanotubes demonstrate superior electrochemical performance (Supplementary Fig. 8m).

The $\mathrm{Co}_{3} \mathrm{O}_{4}$ mesoporous nanotubes are very uniform with a diameter of $\sim 50 \mathrm{~nm}$, and only contain $\sim 5 \mathrm{~nm}$ nanoparticles on the tubes (Fig. 5e, Supplementary Fig. 10). A micro-supercapacitor device based on these nanotubes was fabricated on a silicon wafer (The fabrication process of micro-supercapacitor device is clearly illustrated in Supplementary Fig. 10). These cyclic voltammograms reveal the exceptionally enhanced electrochemical performance of this material (Fig. 5f). 25.0, 24.0 and $18.9 \mathrm{~F} \mathrm{~cm}^{-3}$ for stack capacitance are obtained at the scan rates of $0.01,0.1$ and $1 \mathrm{~V} \mathrm{~s}^{-1}$, respectively (Fig. $5 \mathrm{~g}$ ). When tested at a high rate of $10 \mathrm{~V} \mathrm{~s}^{-1}$, it delivers a capacity of $4.5 \mathrm{~F} \mathrm{~cm}^{-3}$, and $98 \%$ of the initial capacity is maintained after cycling as long as 10,000 times (Fig. 5h). All these unveil that $\mathrm{Co}_{3} \mathrm{O}_{4}$ mesoporous nanotubes demonstrate excellent electrochemical performance with respect to both high rate and long life, showing great application potential.

\section{Discussion}

In summary, our findings clearly indicate that the feasible gradient-electrospinning and controlled-pyrolysis methodology, with extensive material diversity, low cost, good repeatability and high yield, provides an efficient strategy to obtain controllable nanotubes for various inorganic materials, which can break through the limitation of the crystal growth orientation of each sample. On the basis of the formation mechanism, we successfully applied this technique to synthesize various multi-element oxides $\left(\mathrm{Li}_{3} \mathrm{~V}_{2}\left(\mathrm{PO}_{4}\right)_{3}, \mathrm{Na}_{3} \mathrm{~V}_{2}\left(\mathrm{PO}_{4}\right)_{3}, \mathrm{Na}_{0.7} \mathrm{Fe}_{0.7} \mathrm{Mn}_{0.3} \mathrm{O}_{2}\right.$ and $\mathrm{LiNi}_{1 / 3} \mathrm{Co}_{1 /}$ $\left.{ }_{3} \mathrm{Mn}_{1 / 3} \mathrm{O}_{2}\right)$, binary-metal oxides $\left(\mathrm{LiMn}_{2} \mathrm{O}_{4}, \mathrm{LiCoO}_{2}, \mathrm{NiCo}_{2} \mathrm{O}_{4}\right.$ and $\left.\mathrm{LiV}_{3} \mathrm{O}_{8}\right)$ and single-metal oxides mesoporous nanotubes $(\mathrm{CuO}$, $\mathrm{Co}_{3} \mathrm{O}_{4}, \mathrm{SnO}_{2}$ and $\mathrm{MnO}_{2}$ ). Therefore, we believe this technique could lead to rapid advancements in the development of $1 \mathrm{D}$ nanostructures. In addition, these novel mesoporous and pea-like nanotubes, which exhibit excellent electrochemical performance in lithium-ion batteries, sodium-ion batteries and supercapacitors, owing to their large surface area, high conductivity and robust structural stability, will have great potentials in not only the energy storage field, but also in numerous other frontiers.

\section{Methods}

Electrospinning $\mathrm{Li}_{3} \mathbf{V}_{\mathbf{2}}\left(\mathrm{PO}_{\mathbf{4}}\right)_{3}$ mesoporous nanotubes. First, the uniform precursor solution for electrospinning was prepared with low-molecular-weight (98-99\% hydrolysed), middle-molecular-weight (86-89\% hydrolysed) and highmolecular-weight (98-99\% hydrolysed) PVA in a weight ratio of 3:2:1 in $20 \mathrm{ml}$ of deionized water. (This same uniform precursor solution was used to prepare the following samples.) $\mathrm{LiOH} \bullet \mathrm{H}_{2} \mathrm{O}, \mathrm{NH}_{4} \mathrm{VO}_{3}$ and $\mathrm{NH}_{4} \mathrm{H}_{2} \mathrm{PO}_{4}$ were also added in a molar ratio of $3: 2: 3$. After the mixture was stirred at $50{ }^{\circ} \mathrm{C}$ for $5 \mathrm{~h}$, a viscous, uniform, transparent yellow precursor solution was obtained. The concentration of the precursor solution was $\sim 9.5 \mathrm{wt} \%$, the average viscosity was measured as $\sim 0.53 \mathrm{dlg}^{-1}$. The relative humidity was maintained at a constant of $\sim 40 \% \mathrm{RH}$, and the temperature was maintained at $\sim 20^{\circ} \mathrm{C}$. The precursor solution was subsequently electrospun at a constant flow rate of $\sim 1 \mathrm{ml} \mathrm{h}^{-1}$ and at a high voltage of $20 \mathrm{kV}$ (electrospinning equipment: SS-2534H from UCALERY Co., Beijing, China). The distance between the injector nozzle and the receiver was $15 \mathrm{~cm}$. The composite nanowires were collected on revolving aluminium foil. After drying at $80^{\circ} \mathrm{C}$ for $12 \mathrm{~h}$, the composite nanowires were presintered at $300^{\circ} \mathrm{C}\left(10^{\circ} \mathrm{C} \mathrm{min}^{-1}\right)$ in air for $3 \mathrm{~h}$. The sample was then annealed at $800^{\circ} \mathrm{C}\left(5^{\circ} \mathrm{C} \mathrm{min}{ }^{-1}\right)$ under an argon atmosphere for $6 \mathrm{~h}$ to fully carbonize the decomposed PVA. Finally, uniform $\mathrm{Li}_{3} \mathrm{~V}_{2}\left(\mathrm{PO}_{4}\right)_{3}$ mesoporous nanotubes were obtained with a $7 \%$ carbon content (Supplementary Fig. 4). 
Electrospinning $\mathbf{N a}_{\mathbf{3}} \mathbf{V}_{\mathbf{2}}\left(\mathbf{P O}_{\mathbf{4}}\right)_{3}$ mesoporous nanotubes. $\mathrm{NH}_{4} \mathrm{VO}_{3}$ and $\mathrm{NaH}_{2}$ $\mathrm{PO}_{4} \bullet 2 \mathrm{H}_{2} \mathrm{O}$ were added in a molar ratio of $2: 3$ to the prepared PVA precursor. Then the precursor was electrospun at a high voltage of $20 \mathrm{kV}$. After the electrospinning process, the composite nanowires were sintered at $300^{\circ} \mathrm{C}$ $\left(10^{\circ} \mathrm{C} \mathrm{min}^{-1}\right)$ in air for $5 \mathrm{~h}$ and then annealed at $800^{\circ} \mathrm{C}\left(5^{\circ} \mathrm{C} \mathrm{min}{ }^{-1}\right)$ in an argon atmosphere for $5 \mathrm{~h}$.

Electrospinning $\mathbf{N a}_{0.7} \mathrm{Fe}_{0.7} \mathbf{M n}_{\mathbf{0 . 3}} \mathrm{O}_{\mathbf{2}}$ mesoporous nanotubes. $\mathrm{NaNO}_{3}$, $\mathrm{Fe}\left(\mathrm{NO}_{3}\right)_{3} \bullet 9 \mathrm{H}_{2} \mathrm{O}$, and $\mathrm{Mn}\left(\mathrm{CH}_{3} \mathrm{COO}\right)_{2} \bullet 4 \mathrm{H}_{2} \mathrm{O}$ were added in a molar ratio of 7:7:3 to the prepared PVA precursor. Then the precursor was electrospun at a high voltage of $20 \mathrm{kV}$. After the electrospinning process, the composite nanowires were first sintered at $300^{\circ} \mathrm{C}\left(10^{\circ} \mathrm{C} \mathrm{min}{ }^{-1}\right)$ in air for $5 \mathrm{~h}$ and then annealed at $700^{\circ} \mathrm{C}$ $\left(5^{\circ} \mathrm{C} \min ^{-1}\right)$ under argon for $8 \mathrm{~h}$.

Electrospinning $\mathrm{LiNi}_{1 / 3} \mathrm{CO}_{1 / 3} \mathrm{Mn}_{1 / 3} \mathrm{O}_{2}$ mesoporous nanotubes. $\mathrm{CH}_{3} \mathrm{COOLi} \bullet 2 \mathrm{H}_{2} \mathrm{O}, \mathrm{Ni}\left(\mathrm{CH}_{3} \mathrm{COO}\right)_{2} \bullet 4 \mathrm{H}_{2} \mathrm{O}, \mathrm{Mn}\left(\mathrm{CH}_{3} \mathrm{COO}\right)_{2} \bullet 4 \mathrm{H}_{2} \mathrm{O}$ and $\mathrm{Co}\left(\mathrm{CH}_{3} \mathrm{COO}\right)_{2} \bullet 4 \mathrm{H}_{2} \mathrm{O}$ were added in a molar ratio of 3:1:1:1. Then the precursor was electrospun at a high voltage of $20 \mathrm{kV}$. After the electrospinning process, the composite nanowires were annealed at $700{ }^{\circ} \mathrm{C}\left(5^{\circ} \mathrm{C} \mathrm{min}^{-1}\right)$ in air for $5 \mathrm{~h}$.

Electrospinning $\mathrm{LiMn}_{2} \mathrm{O}_{4}$ mesoporous nanotubes. $\mathrm{CH}_{3} \mathrm{COOLi} \bullet 2 \mathrm{H}_{2} \mathrm{O}$ and $\mathrm{Mn}\left(\mathrm{CH}_{3} \mathrm{COO}\right)_{2} \bullet 4 \mathrm{H}_{2} \mathrm{O}$ were added in a molar ratio of $1: 2$ to the prepared PVA precursor. The precursor was electrospun at a high voltage of $18 \mathrm{kV}$. After the electrospinning process, the composite nanowires were annealed at $700{ }^{\circ} \mathrm{C}$ $\left(5^{\circ} \mathrm{C} \mathrm{min}{ }^{-1}\right)$ in air for $5 \mathrm{~h}$.

Electrospinning $\mathrm{LiCoO}_{2}$ mesoporous nanotubes. $\mathrm{CH}_{3} \mathrm{COOLi} \bullet 2 \mathrm{H}_{2} \mathrm{O}$ and $\mathrm{Co}\left(\mathrm{CH}_{3} \mathrm{COO}\right)_{2} \bullet 4 \mathrm{H}_{2} \mathrm{O}$ were added in a molar ratio of $1: 1$ to the prepared PVA precursor. The precursor was electrospun at a high voltage of $18 \mathrm{kV}$. After the electrospinning process, the composite nanowires were sintered at $500{ }^{\circ} \mathrm{C}$ $\left(10^{\circ} \mathrm{Cmin}^{-1}\right)$ in air for $5 \mathrm{~h}$.

Electrospinning $\mathrm{NiCO}_{2} \mathrm{O}_{4}$ mesoporous nanotubes. $\mathrm{Ni}\left(\mathrm{CH}_{3} \mathrm{COO}\right)_{2} \bullet 4 \mathrm{H}_{2} \mathrm{O}$ and $\mathrm{Co}\left(\mathrm{CH}_{3} \mathrm{COO}\right)_{2} \bullet 4 \mathrm{H}_{2} \mathrm{O}$ were added in a molar ratio of $1: 2$ to the prepared PVA precursor. The precursor was electrospun at a high voltage of $18 \mathrm{kV}$. After the electrospinning process, the composite nanowires were sintered at $400^{\circ} \mathrm{C}$ $\left(10^{\circ} \mathrm{C} \min ^{-1}\right)$ in air for $5 \mathrm{~h}$.

Electrospinning $\mathrm{LiV}_{\mathbf{3}} \mathrm{O}_{\mathbf{8}}$ mesoporous nanotubes. $\mathrm{LiOH} \bullet \mathrm{H}_{2} \mathrm{O}$ and $\mathrm{NH}_{4} \mathrm{VO}_{3}$ were added in a molar ratio of 1:3. The precursor was electrospun at a high voltage of $18 \mathrm{kV}$. After the electrospinning process, the composite nanowires were sintered at $450^{\circ} \mathrm{C}\left(10^{\circ} \mathrm{C} \mathrm{min}-1\right)$ in air for $5 \mathrm{~h}$

Electrospinning CuO mesoporous nanotubes. A moderate amount of $\mathrm{Cu}\left(\mathrm{NO}_{3}\right)_{2}$ was added to the prepared PVA precursor. The precursor was electrospun at a high voltage of $16 \mathrm{kV}$. After the electrospinning process, the composite nanowires were sintered at $350^{\circ} \mathrm{C}\left(10^{\circ} \mathrm{C} \mathrm{min}^{-1}\right)$ in air for $5 \mathrm{~h}$.

Electrospinning $\mathrm{CO}_{3} \mathrm{O}_{4}$ mesoporous nanotubes. A moderate amount of $\mathrm{Co}\left(\mathrm{CH}_{3} \mathrm{COO}\right)_{2} \bullet 4 \mathrm{H}_{2} \mathrm{O}$ was added to the prepared PVA precursor. The precursor was electrospun at a high voltage of $16 \mathrm{kV}$. After electrospinning, the composite nanowires were sintered at $350^{\circ} \mathrm{C}\left(10^{\circ} \mathrm{C} \mathrm{min}{ }^{-1}\right)$ in air for $5 \mathrm{~h}$. The carbon from PVA was removed via the sintering process.

Electrospinning $\mathrm{MnO}_{2}$ mesoporous nanotubes. A moderate amount of $\mathrm{Mn}\left(\mathrm{CH}_{3} \mathrm{COO}\right)_{2} \bullet 4 \mathrm{H}_{2} \mathrm{O}$ was added to the prepared PVA precursor. Then the precursor was electrospun at a high voltage of $16 \mathrm{kV}$. After the electrospinning process, the composite nanowires were sintered at $350^{\circ} \mathrm{C}\left(10^{\circ} \mathrm{C} \mathrm{min}^{-1}\right)$ in air for $5 \mathrm{~h}$.

Electrospinning $\mathrm{SnO}_{2}$ mesoporous nanotubes. A moderate amount of $\mathrm{SnCl}_{4}$ was added to the prepared PVA precursor. The precursor was electrospun at a high voltage of $16 \mathrm{kV}$. After the electrospinning process, the composite nanowires were sintered at $500^{\circ} \mathrm{C}\left(10^{\circ} \mathrm{Cmin}^{-1}\right)$ in air for $5 \mathrm{~h}$.

Electrospinning $\mathrm{Li}_{3} \mathbf{V}_{\mathbf{2}}\left(\mathrm{PO}_{4}\right)_{3}$ pea-like nanotubes. The preliminary electrospinning process was the same as that used to prepare the mesoporous nanotubes. After drying at $80^{\circ} \mathrm{C}$ for $12 \mathrm{~h}$, the composite nanowires were directly and immediately heated for $1.5 \mathrm{~h}$ in a furnace preheated to $300^{\circ} \mathrm{C}$. After the composite nanowires were annealed at $800^{\circ} \mathrm{C}\left(5^{\circ} \mathrm{C} \mathrm{min}-1\right)$ under an argon atmosphere for $6 \mathrm{~h}$, uniform pea-like $\mathrm{Li}_{3} \mathrm{~V}_{2}\left(\mathrm{PO}_{4}\right)_{3}$ nanotubes with $19 \%$ carbon content were obtained (Supplementary Fig. 4).

Electrospinning Co pea-like nanotubes. An amount of $\mathrm{Co}\left(\mathrm{CH}_{3} \mathrm{COO}\right)_{2} \bullet 4 \mathrm{H}_{2} \mathrm{O}$ was added to the prepared PVA precursor. Then the precursor was electrospun at a high voltage of $16 \mathrm{kV}$. After the electrospinning process, the composite nanowires were presintered in a muffle furnace at $300^{\circ} \mathrm{C}$ for $1.5 \mathrm{~h}$ and then annealed at $600{ }^{\circ} \mathrm{C}$ under argon for $5 \mathrm{~h}$.

Electrospinning $\mathrm{LiCoO}$, pea-like nanotubes. $\mathrm{CH}_{3} \mathrm{COOLi} \bullet 2 \mathrm{H}_{2} \mathrm{O}$ and $\mathrm{Co}\left(\mathrm{CH}_{3}\right.$ $\mathrm{COO})_{2} \bullet 4 \mathrm{H}_{2} \mathrm{O}$ were added in a molar ratio of $1: 1$ to the prepared PVA precursor. Then the precursor was electrospun at a high voltage of $18 \mathrm{kV}$. After the electrospinning process, the composite nanowires were presintered in a muffle furnace at $300^{\circ} \mathrm{C}$ for $1.5 \mathrm{~h}$ then annealed at $600^{\circ} \mathrm{C}\left(5^{\circ} \mathrm{C} \mathrm{min}-1\right)$ under argon for $5 \mathrm{~h}$.

Electrospinning $\mathbf{N a}_{0.7} \mathrm{Fe}_{0.7} \mathbf{M n}_{\mathbf{0 . 3}} \mathrm{O}_{\mathbf{2}}$ pea-like nanotubes. $\mathrm{NaNO}_{3}$, $\mathrm{Fe}\left(\mathrm{NO}_{3}\right)_{3} \bullet 9 \mathrm{H}_{2} \mathrm{O}$, and $\mathrm{Mn}\left(\mathrm{CH}_{3} \mathrm{COO}\right)_{2} \bullet 4 \mathrm{H}_{2} \mathrm{O}$ were added in a molar ratio of 7:7:3. Then the precursor was electrospun at a high voltage of $20 \mathrm{kV}$. After the electrospinning process, the composite nanowires were presintered in a muffle furnace at $300^{\circ} \mathrm{C}$ for $1.5 \mathrm{~h}$ and then annealed at $700^{\circ} \mathrm{C}\left(5^{\circ} \mathrm{C} \mathrm{min}-1\right)$ under argon for $8 \mathrm{~h}$.

Morphology and structure characterizations. The crystallographic information of the final products was measured using a Bruker D8 Advance X-ray diffractometer equipped with a $\mathrm{Cu} \mathrm{K} \alpha$ radiation source; the samples were scanned over the $2 \theta$ range from $10^{\circ}$ to $80^{\circ}$ at room temperature. SEM images were collected using a JEOL-7100F SEM, and TEM images were collected using a JEM-2100F TEM. The BET surface area was calculated from nitrogen adsorption isotherms measured at $77 \mathrm{~K}$ using a Tristar-3020 instrument. Energy-dispersive X-ray spectra were recorded using an Oxford IE250 system. thermogravimetric-DSC analyses were conducted using a STA-449C. X-ray photoelectron spectroscopy analysis was conducted on a VG Multilab 2000. Raman spectra were obtained using a Renishaw INVIA micro-Raman spectroscopy system. The surface tension was tested by an automatic surface tensiometer (CC2L202) from 2 to $200 \mathrm{~N} \mathrm{~m}^{-1}$.

Preparation of $\mathbf{L i}_{3} \mathbf{V}_{\mathbf{2}}\left(\mathbf{P O}_{\mathbf{4}}\right)_{\mathbf{3}}$ lithium half cells. The 2016 coin cells were assembled in a glovebox filled with pure argon gas. Lithium foil was used as the anode, and a solution of $\operatorname{LiPF}_{6}(1 \mathrm{M})$ in EC/DEC $(1: 1 \mathrm{vol} / \mathrm{vol})$ was used as the electrolyte. The cathode was composed of a ground mixture of $70 \% \mathrm{Li}_{3} \mathrm{~V}_{2}\left(\mathrm{PO}_{4}\right)_{3}$ active material, $20 \%$ acetylene black and $10 \%$ poly(tetrafluoroethylene). After coating onto aluminium foil, the cathode was cut into round slice with $\sim 0.36 \mathrm{~cm}^{2}$ in area and $\sim 0.1 \mathrm{~mm}$ in thickness. And the loading rate of $\mathrm{Li}_{3} \mathrm{~V}_{2}\left(\mathrm{PO}_{4}\right)_{3}$ active material was $\sim 2 \mathrm{mg}$ for one 2016 coin cell.

Preparation of $\mathrm{Li}_{\mathbf{3}} \mathbf{V}_{\mathbf{2}}\left(\mathbf{P O}_{\mathbf{4}}\right)_{3} / \mathrm{Li}_{\mathbf{4}} \mathbf{T i}_{5} \mathbf{O}_{\mathbf{1 2}}$ full batteries. The $\mathrm{Li}_{3} \mathrm{~V}_{2}\left(\mathrm{PO}_{4}\right)_{3} / \mathrm{Li}_{4} \mathrm{Ti}_{5} \mathrm{O}_{12}$ battery was also assembled in a glovebox filled with pure argon gas. $\mathrm{Li}_{3} \mathrm{~V}_{2}\left(\mathrm{PO}_{4}\right)_{3}$ was coated onto aluminium foil as the cathode, and $\mathrm{Li}_{4} \mathrm{Ti}_{5} \mathrm{O}_{12}$ was coated onto copper foil as the anode.

Preparation of $\mathbf{N a}_{0.7} \mathbf{F e}_{0.7} \mathbf{M n}_{0.3} \mathbf{O}_{\mathbf{2}}$ sodium batteries. The 2016 coin cells were assembled in a glovebox filled with pure argon gas. Sodium foil was used as the anode, and $1 \mathrm{M} \mathrm{NaClO}_{4}$ in a mixture of ethylene carbonate/dimethyl carbonate (1:2 in weight) with trace propylene carbonate (electrolyte additive) was used as the electrolyte. The prepared cathodes contained $70 \% \mathrm{Na}_{0.7} \mathrm{Fe}_{0.7} \mathrm{Mn}_{0.3} \mathrm{O}_{2}$ active material, $20 \%$ acetylene black and $10 \%$ polyvinylidene difluoride (using $\mathrm{N}$-methylpyrrolidone as the solvent). After coating onto aluminium foil, the cathode was cut into round slice with $\sim 0.36 \mathrm{~cm}^{2}$ in area and $\sim 0.1 \mathrm{~mm}$ in thickness, and the loading rate of $\mathrm{Na}_{0.7} \mathrm{Fe}_{0.7} \mathrm{Mn}_{0.3} \mathrm{O}_{2}$ was $\sim 2.5 \mathrm{mg}$ for one 2016 coin cell.

Preparation of $\mathrm{CO}_{3} \mathrm{O}_{4}$ supercapacitors. Electrochemical measurements were performed within the potential window of -0.2 to $0.4 \mathrm{~V}$ using an Autolab potentiostat/galvanostat (Autolab PGSTAT $302 \mathrm{~N}$ ) in a three-electrode configuration with $1 \mathrm{M} \mathrm{NaOH}$ aqueous solution as the electrolyte; the measurements were performed at room temperature. A $1-\mathrm{cm}^{2}$ piece of silicon wafer on which the $\mathrm{Co}_{3} \mathrm{O}_{4}$ mesoporous nanotubes were deposited was directly used as the working electrode (Supplementary Fig. 10). The reference and counter electrodes were an $\mathrm{Ag} / \mathrm{KCl}$ electrode and a platinum plate, respectively.

Electrochemical measurements. Galvanostatic charge/discharge measurements were performed using a multichannel battery testing system (LAND CT2001A). Cyclic voltammograms and electrochemical impedance spectra were collected at room temperature using an Autolab potentiostat/galvanostat.

\section{References}

1. Armand, M. \& Tarascon, J.-M. Building better batteries. Nature 451, 652-657 (2008).

2. Noorden, R. V. A better battery. Nature 507, 26-28 (2014).

3. $\mathrm{Wu}, \mathrm{H}$. et al. Stable cycling of double-walled silicon nanotube battery anodes through solid-electrolyte interphase control. Nat. Nanotechnol. 7, 310-315 (2012). 
4. Zhao, Y. \& Jiang, L. Hollow micro/nanomaterials with multilevel interior structures. Adv. Mater. 21, 3621-3638 (2009).

5. Huang, Y., Duan, X. F., Wei, Q. Q. \& Lieber, C. M. Directed assembly of one-dimensional nanostructures into functional networks. Science 291, 630-633 (2001)

6. Jung, H. G., Jang, M. W., Hassoun, J., Sun, Y. K. \& Scrosati, B. A high-rate longlife $\mathrm{Li}_{4} \mathrm{Ti}_{5} \mathrm{O}_{12} / \mathrm{Li}\left[\mathrm{Ni}_{0.45} \mathrm{Co}_{0.1} \mathrm{Mn}_{1.45}\right] \mathrm{O}_{4}$ lithium-ion battery. Nat. Commun. 2, 516 (2011).

7. Yang, F. et al. Chirality-specific growth of single-walled carbon nanotubes on solid alloy catalysts. Nature 510, 522-524 (2014).

8. Qin, Y., Lee, S.-M., Pan, A. L., Gösele, U. \& Knez, M. Rayleigh-instabilityinduced metal nanoparticle chains encapsulated in nanotubes produced by atomic layer deposition. Nano Lett. 8, 114-118 (2008).

9. Lee, S. W. et al. High-power lithium batteries from functionalized carbonnanotube electrodes. Nat. Nanotechnol. 5, 531-537 (2010).

10. Wang, X., Zhuang, J., Peng, Q. \& Li, Y. D. A general strategy for nanocrystal synthesis. Nature 43, 121-124 (2005).

11. Magasinski, A. et al. High-performance lithium-ion anodes using a hierarchical bottom-up approach. Nat. Mater. 9, 353-358 (2010).

12. Deng, Y. H., Wei, J., Sun, Z. K. \& Zhao, D. Y. Large-pore ordered mesoporous materials templated from non-Pluronic amphiphilic block copolymers. Chem. Soc. Rev. 42, 4054-4070 (2013).

13. Yao, J., Yan, H. \& Lieber, C. M. A nanoscale combing technique for the large-scale assembly of highly aligned nanowires. Nat. Nanotechnol. 8, 329-335 (2013).

14. Chen, C. et al. Highly crystalline multimetallic nanoframes with threedimensional electrocatalytic surfaces. Science 343, 1339-1343 (2014).

15. Joshi, R. K. \& Schneider, J. J. Assembly of one dimensional inorganic nanostructures into functional 2D and 3D architectures. Synthesis, arrangement and functionality. Chem. Soc. Rev. 41, 5285-5312 (2012)

16. Yaman, M. et al. Arrays of indefinitely long uniform nanowires and nanotubes. Nat. Mater. 10, 494-501 (2011)

17. Ren, Y., Ma, Z. \& Bruce., P. G. Ordered mesoporous metal oxides: synthesis and applications. Chem. Soc. Rev. 41, 4909-4927 (2012).

18. Xia, Y. N. et al. One-dimensional nanostructures: synthesis, characterization and applications. Adv. Mater. 15, 353-389 (2003).

19. Li, D. \& Xia, Y. N. Electrospinning of nanofibers: reinventing the wheel? Adv. Mater. 16, 1151-1170 (2004).

20. Li, D., MaCann, J. T. \& Xia, Y. N. Electrospinning: a simple and versatile technique for producing ceramic nanofibers and nanotubes. J. Am. Ceram. Soc. 89, 1861-1869 (2006).

21. Yuan, C. Z., Wu, H. B., Xie, Y. \& Lou, X. W. Mixed transition-metal oxides: design, synthesis, and energy-related applications. Angew. Chem. Int. Ed. 53, 1488-1504 (2014)

22. Mai, L. Q. et al. Electrospun ultralong hierarchical vanadium oxide nanowires with high performance for lithium ion batteries. Nano Lett. 10, 4750-4755 (2010).

23. Wu, J., Wang, N., Zhao, Y. \& Jiang, L. Electrospinning of multilevel structured functional micro-/nanofibers and their applications. J. Mater. Chem. A 1, 7290-7305 (2013).

24. Zussman, E., Yarin, A. L., Bazilevsky, A. V., Avrahami, R. \& Feldman, M. Electrospun polyacrylonitrile/poly(methyl methacrylate)-derived turbostratic carbon micro-/nanotubes. Adv. Mater. 18, 348-353 (2006).

25. Zhan, S. H., Chen, D. R., Jiao, X. L. \& Tao, C. H. Long $\mathrm{TiO}_{2}$ hollow fibers with mesoporous walls: sol-gel combined electrospun fabrication and photocatalytic properties. J. Phys. Chem. B 110, 11199-11204 (2006).

26. Hou, H. L. et al. General strategy for fabricating thoroughly mesoporous nanofibers. J. Am. Chem. Soc. 136, 16716-16719 (2014).

27. Sun, Y. G., Mayers, B. \& Xia, Y. N. Metal nanostructures with hollow interiors. Adv. Mater. 15, 641-646 (2003).

28. Li, D. \& Xia, Y. N. Direct fabrication of composite and ceramic hollow nanofibers by electrospinning. Nano Lett. 4, 933-938 (2004).

29. McCann, J. T., Marquez, M. \& Xia, Y. N. Melt coaxial electrospinning: a versatile method for the encapsulation of solid materials and fabrication of phase change nanofibers. Nano Lett. 6, 2868-2872 (2006).

30. Zhao, Y., Cao, X. Y. \& Jiang, L. Bio-mimic multichannel microtubes by a facile method. J. Am. Chem. Soc. 129, 764-765 (2007).

31. Shin, Y. M., Hohman, M. M., Brenner, M. P. \& Rutledge, G. C. Experimental characterization of electrospinning: the electrically forced jet and instabilities. Polymer (Guildf). 42, 9955-9967 (2001).

32. Fridrikh, S. V., Yu, J. H., Brenner, M. P. \& Rutledge, G. C. Controlling the fiber diameter during electrospinning. Phys. Rev. Lett. 90, 144502 (2003).
33. Wu, Z. X. et al. A general "surface-locking" approach toward fast assembly and processing of large-sized, ordered, mesoporous carbon microspheres. Angew. Chem. Int. Ed. 52, 13764-13768 (2013).

34. Theron, A., Zussman, E. \& Yarin, A. L. Electrostatic field-assisted alignment of electrospun nanofibres. Nanotechonolgy 12, 384-390 (2001).

35. Liu, H. et al. Capturing metastable structures during high-rate cycling of $\mathrm{LiFePO}_{4}$ nanoparticle electrodes. Science 344, 1480 (2014).

36. Yang, P. D., Zhao, D. Y., Margolese, D. I., Chmelka, B. F. \& Stucky, G. D. Generalized syntheses of large-pore mesoporous metal oxides with semicrystalline frameworks. Nature 396, 152-155 (1998).

37. Kang, B. \& Ceder, G. Battery materials for ultrafast charging and discharging. Nature 458, 190-193 (2009).

38. Nishijima, M. et al. Accelerated discovery of cathode materials with prolonged cycle life for lithium-ion battery. Nat. Commun. 5, 4553 (2015).

39. Mai, L. Q., Tian, X. C., Xu, X., Chang, L. \& Xu, L. Nanowire electrodes for electrochemical energy storage devices. Chem. Rev. 114, 11828-11862 (2014).

40. Masquelier, C. \& Croguennec, L. Polyanionic (phosphates, silicates, sulfates) frameworks as electrode materials for rechargeable $\mathrm{Li}$ (or $\mathrm{Na}$ ) batteries. Chem Rev. 113, 6552-6591 (2013).

41. Yabuuchi, N. et al. $\mathrm{P} 2$-type $\mathrm{Na}_{\mathrm{x}}\left[\mathrm{Fe}_{1 / 2} \mathrm{Mn}_{1 / 2}\right] \mathrm{O}_{2}$ made from earth-abundant elements for rechargeable Na batteries. Nat. Mater. 11, 512-517 (2012).

42. Kalluri, S. et al. Electrospun P2-type $\mathrm{Na}_{2 / 3}\left(\mathrm{Fe}_{1 / 2} \mathrm{Mn}_{1 / 2}\right) \mathrm{O}_{2}$ hierarchical nanofibers as cathode material for sodium-ion batteries. ACS Appl. Mater. Interfaces 6, 8953-8958 (2014).

43. Xu, J. et al. Identifying the critical role of $\mathrm{Li}$ substitution in $\mathrm{P} 2-\mathrm{Na}_{\mathrm{x}}\left[\mathrm{Li}_{\mathrm{y}} \mathrm{Ni}_{\mathrm{z}}\right.$ $\left.\mathrm{Mn}_{1-\mathrm{y}-\mathrm{z}}\right] \mathrm{O}_{2}(0<\mathrm{x}, \mathrm{y}, \mathrm{z}<1)$ intercalation cathode materials for high-energy Na-ion batteries. Chem. Mater. 26, 1260-1269 (2014).

44. Oh, S. M. et al. Advanced $\mathrm{Na}\left[\mathrm{Ni}_{0.25} \mathrm{Fe}_{0.5} \mathrm{Mn}_{0.25}\right] \mathrm{O}_{2} / \mathrm{C}-\mathrm{Fe}_{3} \mathrm{O}_{4}$ sodium-ion batteries using EMS electrolyte for energy storage. Nano Lett. 14, 1620-1626 (2014).

45. Wu, Z. S., Parves, K., Feng, X. L. \& Müllen, K. Graphene-based in-plane micro-supercapacitors with high power and energy densities. Nat. Commun. 4, 2487 (2013)

\section{Acknowledgements}

This work was supported by the National Basic Research Program of China (2013CB934103, 2012CB933003), the International Science and Technology Cooperation Program of China (2013DFA50840), the National Natural Science Fund for Distinguished Young Scholars (51425204), the National Natural Science Foundation of China $(51272197,51302203)$, Hubei Province Natural Science Fund for Distinguished Young Scholars (2014CFA035) and the Fundamental Research Funds for the Central Universities (2014-VII-007, 2014-CL-A1-01). We thank Professor C. M. Lieber of Harvard University and Professor J. Liu of Pacific Northwest National Laboratory for useful discussions and assistance with the manuscript. We thank the Center for Materials Research and Analysis from Wuhan University of Technology.

\section{Author contribution}

L.Q.M. and C.J.N. conceived and designed the experiments, analysed the results and wrote the manuscript. J.S.M., X.P.W. and L.X. performed the experiments and analysed the results. All authors commented on the manuscript

\section{Additional information}

Supplementary Information accompanies this paper at http://www.nature.com/ naturecommunications

Competing financial interests: The authors declare no competing financial interests.

Reprints and permission information is available online at http://npg.nature.com/ reprintsandpermissions/

How to cite this article: Niu, C. et al. General synthesis of complex nanotubes by gradient electrospinning and controlled pyrolysis. Nat. Commun. 6:7402 doi: $10.1038 /$ ncomms8402 (2015)

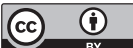

This work is licensed under a Creative Commons Attribution 4.0 International License. The images or other third party material in this article are included in the article's Creative Commons license, unless indicated otherwise in the credit line; if the material is not included under the Creative Commons license, users will need to obtain permission from the license holder to reproduce the material. To view a copy of this license, visit http://creativecommons.org/licenses/by/4.0/ 